Int. J. Electrochem. Sci., 15 (2020) $1082-1090$

\title{
Corrosion and Discharge Performance of Mg-2Zn-0.5Ce-0.5Mn- 0.2Ca Alloy in NaCl Solution
}

Yanchun Zhao ${ }^{1}$, Guangsheng Huang ${ }^{2,3, *}$, Guangang Wang $^{2}$, Zhenghua Yao ${ }^{1}$, Cheng Peng ${ }^{1}$ and Fusheng Pan ${ }^{2,3}$

${ }^{1}$ Chongqing Key Laboratory of Extraordinary Bond Engineering and Advanced Materials Technology, Yangtze Normal University, Chongqing 408100, China

${ }^{2}$ State Key Laboratory of Mechanical Transmission, Chongqing University, Chongqing 400044, China

${ }^{3}$ National Engineering Research Center for Magnesium Alloys, Chongqing University, Chongqing 400044, China

*E-mail: gshuang@cqu.edu.cn

doi: $10.20964 / 2020.02 .19$

Received: 4 October 2019 / Accepted: 18 November 2019 / Published: 31 December 2019

In this study, $\mathrm{Mg}-2 \mathrm{Zn}-0.5 \mathrm{Ce}-0.5 \mathrm{Mn}-0.2 \mathrm{Ca}$ alloy was prepared. The corrosion and discharge properties of the alloy in $3.5 \mathrm{wt} . \% \mathrm{NaCl}$ solution was studied and compared with those of an AZ31 alloy. The $\mathrm{Mg}-2 \mathrm{Zn}-0.5 \mathrm{Ce}-0.5 \mathrm{Mn}-0.2 \mathrm{Ca}$ alloy exhibits higher corrosion resistance than that of the AZ31 alloy. The corrosion current densities of the $\mathrm{Mg}-2 \mathrm{Zn}-0.5 \mathrm{Ce}-0.5 \mathrm{Mn}-0.2 \mathrm{Ca}$ and AZ31 alloys are $0.31 \mathrm{~mA} \mathrm{~cm}$ and $0.54 \mathrm{~mA} \mathrm{~cm}{ }^{2}$, respectively. The $\mathrm{Mg}-2 \mathrm{Zn}-0.5 \mathrm{Ce}-0.5 \mathrm{Mn}-0.2 \mathrm{Ca}$ alloy also exhibits better discharging performance, such as a higher discharge voltage and anodic efficiency, than that of the AZ31 alloy. The average discharge potentials of the $\mathrm{Mg}-2 \mathrm{Zn}-0.5 \mathrm{Ce}-0.5 \mathrm{Mn}-0.2 \mathrm{Ca}$ and $\mathrm{AZ} 31$ anodes are $-1.45 \mathrm{~V}$ and $-1.31 \mathrm{~V} \mathrm{~mA} \mathrm{~cm}{ }^{2}$, respectively. The anodic efficiencies of the $\mathrm{Mg}-2 \mathrm{Zn}-0.5 \mathrm{Ce}-0.5 \mathrm{Mn}-0.2 \mathrm{Ca}$ and AZ31 anodes are $62.1 \%$ and $53.8 \%$, respectively. Thus, the $\mathrm{Mg}-2 \mathrm{Zn}-0.5 \mathrm{Ce}-0.5 \mathrm{Mn}-0.2 \mathrm{Ca}$ alloy is a good candidate as an anode material for $\mathrm{Mg}$ batteries.

Keywords: $\mathrm{Mg}-2 \mathrm{Zn}-0.5 \mathrm{Ce}-0.5 \mathrm{Mn}-0.2 \mathrm{Ca}$ alloy; Corrosion resistance; Discharge potential; Anodic efficiency

\section{FULL TEXT}

(C) 2020 The Authors. Published by ESG (www.electrochemsci.org). This article is an open access article distributed under the terms and conditions of the Creative Commons Attribution license (http://creativecommons.org/licenses/by/4.0/). 